\title{
DP-MS-81-54
}

CONF-811122-- 6

\section{VITRIFICATION OF HIGH-LEVEL RADIOACTIVE WASTE \\ IN A SMALL-SCALE JOULE-HEATED CERAMIC MELTER}

by

Gerald B. Woolsey and M. John Plodinec

E. I. du Pont de Nemours \& Co.

Savannah River Laboratory

Aiken, South Carolina 29808

A Paper* Proposed for Presentation

at the Materials Research Society

Annual Meeting in Boston, Massachusetts, on November 15-20,1981, and for

Publication in Scientific Basis for

Nuclear Waste Management 4.

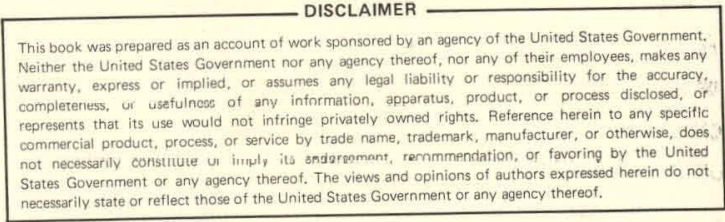

* This paper was prepared in connection with work done under Contract No. DE-ACn9-76SR00001 with the U.S. Department of Energy. By acceptance of this paper, the publisher and/or recipient acknowledges the U.S. Government's right to retain a nonexclusive, royalty-free license in and to any copyright covering this paper, along with the right to reproduce and to authorize others to reproduce all or part of the copyrighted paper. 


\section{DISCLAIMER}

This report was prepared as an account of work sponsored by an agency of the United States Government. Neither the United States Government nor any agency Thereof, nor any of their employees, makes any warranty, express or implied, or assumes any legal liability or responsibility for the accuracy, completeness, or usefulness of any information, apparatus, product, or process disclosed, or represents that its use would not infringe privately owned rights. Reference herein to any specific commercial product, process, or service by trade name, trademark, manufacturer, or otherwise does not necessarily constitute or imply its endorsement, recommendation, or favoring by the United States Government or any agency thereof. The views and opinions of authors expressed herein do not necessarily state or reflect those of the United States Government or any agency thereof. 


\section{DISCLAIMER}

Portions of this document may be illegible in electronic image products. Images are produced from the best available original document. 


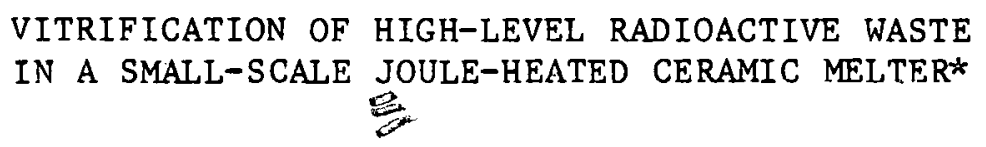

GERALD B. WOOLSEY AND M. JOHN PLODINEC

E. I. du Pont de Nemours \& Co., Savannah River Laboratory, Aiken, South Carolina 29808

\section{ABSTRACT}

Vitrification is the reference process for the immobilization of radioactive waste from the production of defense materials at the Savannah River Plant (SRP). Since 1979, a small vitrification facility $(1 \mathrm{lb} / \mathrm{hr})$ has been operated at the Savannah River Laboratory using actual SRP waste. In previous studies, dried waste was fed to this smaller melter. This report discusses direct feeding of actual 1 iquid-waste slurries to the small melter. These liquidfeeding tests demonstrated that addition of premelted glass frit to the waste slurry reduces the amount of material volatilized. Results of these tests are in accord with results of large-scale tests with actual waste.

* The information contained in this article was developed during the course of work under Contract No. DE-ACO976SRO0001 with the U.S. Department of Energy. 


\section{INTRODUCTION}

Radioactive waste produced from reprocessing nuclear fuel for defense programs at the Savannah River Plant (SRP) is stored in large underground tanks on the plant site. This alkaline waste is made up of three components. The bulk of the waste actinides and fission products is contained in an insoluble sludge of hydroxides and hydrous oxides of iron, aluminum, and manganese [1-3]. The rest of the waste is either in the form of a crystalline salt cake or a nearlysaturated supernatant salt solution. This supernatant solution contains nearly all the radiocesium and traces of other radionuclides [4].

Methods to immobilize SRP waste for longterm storage are presently being developed at the Savannah River Laboratory (SRL). It is currently envisioned that the waste will be immobilized in two stages. This will reduce the initial capital investment and allow the most efficient use of limited resources. Since $-95 \%$ of the radionuclides are cont ained in the insoluble sludge, the first stage will be designed to immobilize the sludge. A second stage for processing highlevel waste salt would be built a few years 1 ater.

According to the current reference process, sludge (washed free of soluble salts) will be mixed with glass-forming chemicals (in the form of premelted borosilicate glass frit). This slurry will be heated to drive off excess water, then fed to a Joule-heated ceramic melter. Here the slurry will be dried and dissolved in the molten frit. The glass formed will be continuously poured out of the melter into stainless steel canisters. These canisters will be welded closed and then stored on-site on an interim basis. Eventually they would be shipped to a Federal repository for permanent storage.

Since 1977, SRL has been performing continuous melting tests with simulated waste using both large-scale and small-scale equipment. In early 1979, SRL began processing actual waste in a small-scale glass plant in hot cells (capacity -1 lb/hour). In earlier work [5], a dry mixture of glass frit and sludge was fed to the small-scale continuous melter. Recent advances in feeding rechnology. have led to a method of water-slurry feeding which has now been demonstrated with actual waste. This has allowed considerable simplification of the vitrification process.

This report summarizes the results of successful slurry-fed vitrification tests. Volatilities of cesium and ruthenium decreased when premelted glass frit was added to the waste (cesium volatility decreased by a factor of 10 , to about $1 \%)$. These tests showed that slurry-fed vitrification can immobilize SRP waste easily, with minimal volatilization of radionuclides.

\section{PROCEDURE AND EQUIPMENT}

A 30-liter sample of Tank 15 waste (Table I) was washed with hot caustic to remove about $75 \%$ of the soluble aluminum, and then water-washed twice more to remove soluble salts. The 30 wt $\%$ solids slurry was then fed to a small-scale joule-heated melter.

The composition of the gases emitted during vitrification was studied by collecting them in a gas treatment system. Semivolatile components, such as cesium and ruthenium, were collected in a semivolatiles trap of removable rings

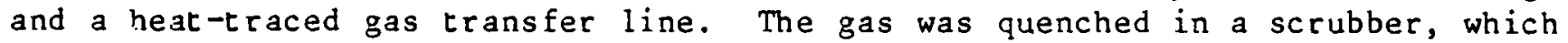
removed water and entrained particulate material. Backup absorption beds for 
volatile ruthenium and iodine were also provided. The entire system (shown schematically in Fig. 1) operated under a slight vacuum. In practice, no radioactive material was detected downstream of the scrubber. At the start of the experiment, the melter was charged with Frit 131 (Table II) [6] and a 1/2inch layer of graphite. When melter temperatures were reached, a slurry of water and Tank 15 waste only was fed to the glass to build up the waste concentration (Step A). Then the normal slurry ( $10 \%$ sludge, $20 \%$ frit) was fed (Step B). The results from feeding the waste by itself indicate the volatility to be expected if frit were inadvertently omitted from a batch of melter feed, or if severe feed segregation occurred.

\section{VOLATILITY OF RADIONUCLIDES}

The relative amounts of several radionuclides collected in the off-gas system are shown in Table III. When frit was added to the waste, the amounts of volatilized cesium and ruthenium dropped significantly, but the amounts of technetium and strontium remained fairly constant. This pattern is consistent with loss of cesium and ruthenium by volatilization and loss of strontium and technetium by particle entrainment.

However, the deposition pattern of technetium forces modification of this simple picture. In the absence of frit; technetium apparently volatilized as a high-temperature compound which decomposes at $650-750^{\circ} \mathrm{C}$ (Fig. 2). The decomposition products were then carried through the system as entrained particulates. When mixed with frit, too little technetium was caught in the semivolatiles trap for meaningful interpretation. However, most of the volatile technetium was again captured in the off-gas line (approximately $350^{\circ} \mathrm{C}$ ).

\section{VOLATILITY OF NONRADIOACTIVE COMPONENTS}

The amounts of chloride and fluoride found in the off-gas system were greatly affected by the presence of. Frit. Although the total amount of chloride collected was roughly the same, in the presence of frit less chloride reached the off-gas line and scrubber. Little fluoride was volatilized when frit was present; about 10 times more was volatilized when frit was absent. In either case, most of the fluoride that was volatilized was found in the off-gas line.

Thus, frit appears to have had no effect on the source of chloride volatility, but may have caused the chloride to condense at higher temperatures. If chloride volatilized as $\mathrm{HCl}$, then the addition of frit would add $\mathrm{NaOH}$ to the vapor, leading to the deposition of particulate $\mathrm{NaCl}$.

\section{COMPARISONS TO LARGE-SCALE TESTS}

The results with actual waste, reported here, agree well for most elements with results obtained on simulated SRP wastes at Battelle-Pacific Northwest Laboratory (PNL). As Table IV shows, results for ruthenium and strontium are very similar. However, cesium and chlorine retention was much higher in the actual waste melter. This may have been due to (1) the chemical form of these components, and (2) the use of supplemental lid heating in the PNL tests. In 1 aboratory tests at SRL, the chloride volatility varied by a factor of 30 . It was lowest when the chloride was precipitated with the waste, as in actual waste. 
Supplemental lid heating is a technique developed to increase the throughput of a slurry-fed melter. In tests at PNL and SRL, supplemental lid heat ing always increased the amount of material going into the off-gas system.

\section{CONCLUSIONS}

These experiments showed that, with proper temperature control and mixing of frit and waste, only about $1 \%$ of the actual waste components fed to the small melter went to the off-gas system. Nonvolatile species, such as strontium, entered the off-gas system by entrainment. Volatile species either entered the off-gas system as vapors, and then condensed (cesium, ruthenium) or volatilized and decomposed above the melt, and were brought into the off-gas system as entrained particulates (technetium). However, for all species, the small offgas treatment system used here effectively removed all traces of radioactivity from the vapor stream.

\section{REFERENCES}

1. R. M. Wallace, H. L. Hull, and R. F. Bradley, "Solid Forms for Savannah River Plant High-Level Waste," USAEC Report DP-1335, E. I. du Pont de Nemours and Company, Savannah River Laboratory, Aiken, SC (1973).

2. J. A. Stone, J. A. Kelley, and T. S. McMillan, "Sampling and Analyses of SRP High-Level Waste Sludges," USERDA Report DP-1399, E. I. du Pont de Nemours and Company, Savannah River Laboratory, Aiken, SC (1976).

3. J. A. Stone, "Separation of SRP Waste Sludge and Supernate," USERDA Report DP-1441, E. I. du Pont de Nemours and Company, Savannah River Laboratory, Aiken, SC (1976).

4. R. S. Ondrejcin, "Chemical Compositions of Supernates Stored in SRP HighLevel Waste Tanks," USAEC Report DP-1347, E. I. du Pont de Nemours and Company, Savannah River Laboratory, Aiken, SC (1974).

5. G. B. Woolsey, "Smal1-Scale Integrated Demonstration of HLW Processing and Vitrification Using Actual SRP Waste," Proceedings of Waste Management 81 , ANS Topical Meering, Tucson, AZ, February 23-26, 1981, pp. 811-823.

6. M. J. Plodinec, "Improved Glass Compositions for Immobilization of SRP Waste," Scientific Basis for Nuclear Waste Management, II, (Clyde J. M. Northrup, ed.) Plenum, NY, 1980, pp. 223-230. 
TABLE I

Composition of tank 15 waste

\begin{tabular}{|c|c|}
\hline Component & Amount (wt \%) \\
\hline $\mathrm{Al}$ & 28.2 \\
\hline $\mathrm{Fe}$ & 5.7 \\
\hline $\mathrm{Hg}$ & 4.6 \\
\hline $\mathrm{NO}_{3}^{-}$ & 4.0 \\
\hline $\mathrm{U}$ & 2.3 \\
\hline $\mathrm{Na}$ & 1.8 \\
\hline $\mathrm{Mn}$ & 1.6 \\
\hline $\mathrm{Si}$ & 1.6 \\
\hline Th & 1.4 \\
\hline $\mathrm{C} 1$ & 0.7 \\
\hline $\mathrm{Ca}$ & 0.5 \\
\hline $\mathrm{Ni}$ & 0.5 \\
\hline $\mathrm{SO}_{4}^{--}$ & 0.5 \\
\hline $\mathrm{Zr}$ & 0.2 \\
\hline $\mathrm{Cr}$ & 0.2 \\
\hline $\mathrm{Mg}$ & 0.1 \\
\hline $\mathrm{Ba}$ & 0.1 \\
\hline${ }^{99} \mathrm{Tc}$ & $1.5 \times 10^{-2}$ \\
\hline${ }^{137} \mathrm{Cs}$ & $1.1 \times 10^{-3}$ \\
\hline${ }^{90} \mathrm{Sr}$ & $2.7 \times 10^{-4}$ \\
\hline $\mathrm{Pu}$ & $2.0 \times 10^{-5}$ \\
\hline
\end{tabular}


TABLE II

Composition of Frit 131

\begin{tabular}{ll}
\hline Component & Amount (Wt \%) \\
\hline $\mathrm{SiO}_{2}$ & 57.9 \\
$\mathrm{Na}_{2} \mathrm{O}$ & 17.7 \\
$\mathrm{~B}_{2} \mathrm{O}_{3}$ & 14.7 \\
$\mathrm{Li}_{2} \mathrm{O}$ & 5.7 \\
$\mathrm{MgO}$ & 2.0 \\
$\mathrm{TiO}_{2}$ & 1.0 \\
$\mathrm{ZrO}_{2}$ & 0.5 \\
$\mathrm{La}_{2} \mathrm{O}_{3}$ & 0.5 \\
\hline
\end{tabular}


TABLE III

Volatility of radionuclides

\begin{tabular}{|c|c|c|c|c|c|}
\hline \multirow{2}{*}{ Radionuclide } & \multirow{2}{*}{$\begin{array}{l}\text { Frit } \\
\text { present ? }\end{array}$} & \multirow{2}{*}{$\begin{array}{l}\text { Amount } \\
\text { volatilized (\%) }\end{array}$} & \multicolumn{2}{|c|}{ Distribution } & \multirow{2}{*}{ Scrubber } \\
\hline & & & Trap & Line & \\
\hline $137 \mathrm{Cs}$ & $\begin{array}{l}\text { No } \\
\text { Ye s }\end{array}$ & $\begin{array}{r}24 \\
1\end{array}$ & $\begin{array}{l}20 \\
0.2\end{array}$ & $\begin{array}{l}4 \\
0.8\end{array}$ & $\begin{array}{l}\sim 0 \\
\sim 0\end{array}$ \\
\hline $106 \mathrm{Ru}$ & $\begin{array}{l}\text { No } \\
\text { Yes }\end{array}$ & $\begin{array}{r}22 \\
5\end{array}$ & $\begin{array}{l}6 \\
1\end{array}$ & $\begin{array}{r}16 \\
4\end{array}$ & $\begin{array}{l}\sim 0 \\
\sim 0\end{array}$ \\
\hline${ }^{99} \mathrm{Tc}$ & $\begin{array}{l}\text { No } \\
\text { Yes }\end{array}$ & $\begin{array}{l}2 \\
2\end{array}$ & $\begin{array}{l}0.3 \\
0.05\end{array}$ & $\begin{array}{l}1.4 \\
2.0\end{array}$ & $\begin{array}{l}0.4 \\
\sim 0\end{array}$ \\
\hline $90 \mathrm{Sr}$ & $\begin{array}{l}\text { No } \\
\text { Yes }\end{array}$ & $\begin{array}{l}6 \\
5\end{array}$ & $\begin{array}{l}6 \\
5\end{array}$ & $\begin{array}{l}\sim 0 \\
\sim 0\end{array}$ & $\begin{array}{l}\sim 0 \\
\sim 0\end{array}$ \\
\hline
\end{tabular}


TABLE IV

Comparison of solubility of actual waste and simulated waste

\begin{tabular}{lll} 
& $\frac{\%}{2}$ of component found in off-gas system ${ }^{a}$ \\
\cline { 2 - 3 } Component & Actual waste (SRL) & Simulated waste (PNL) \\
Strontium & 0.1 to 0.4 & 0.2 to 0.3 \\
Ruthenium & 4 & 2 to 7 \\
Cesium & 0.4 to 4 & 0 to 30 \\
Chloride & 0.7 to 1.2 & 0 to 30
\end{tabular}

a) Fraction of component fed to melter that was found in off-gas system. For actual waste, does not include semivolatiles trap. 


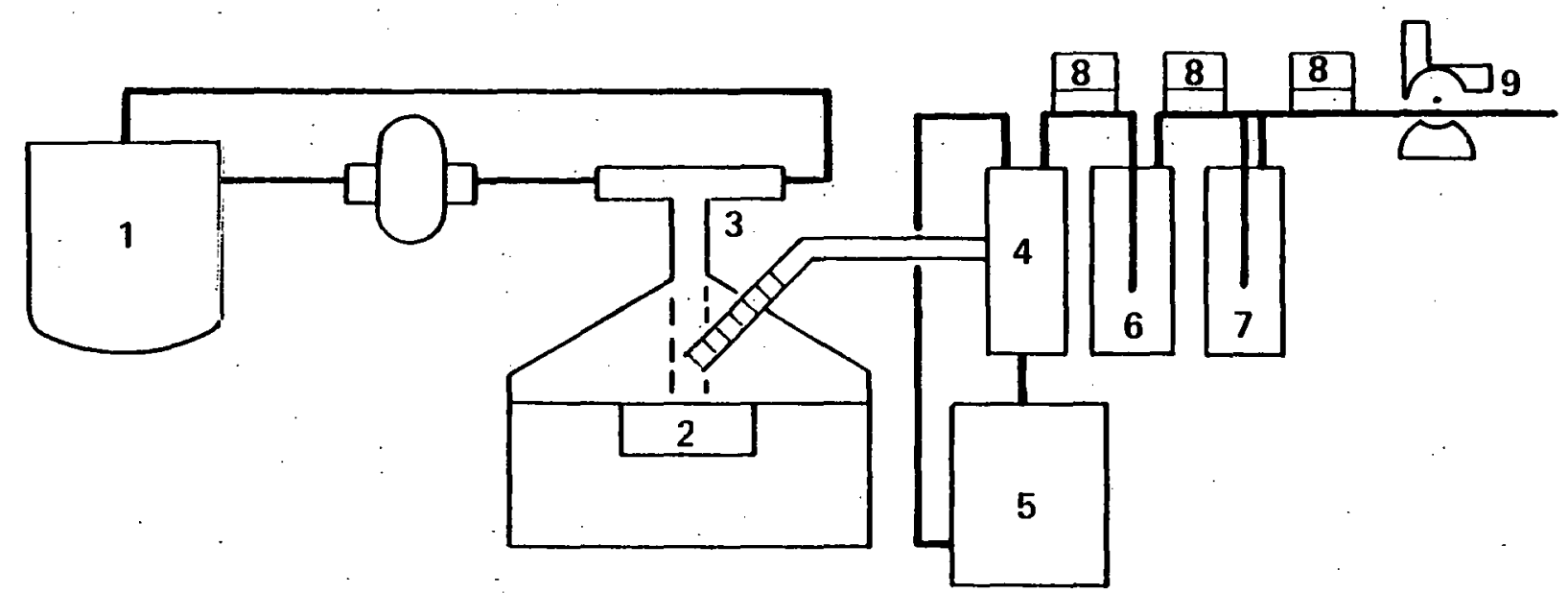
1. Feed Slurry Tank
2. Melt Chamber
6. Ru Trap
7. I Trap
8. NaOH Solution Traps
4. Scrubber
9. Exhaust Fan
5. Scrub Liquid Tank

Fig. 1. Schematic of the small-scale melter off-gas system 


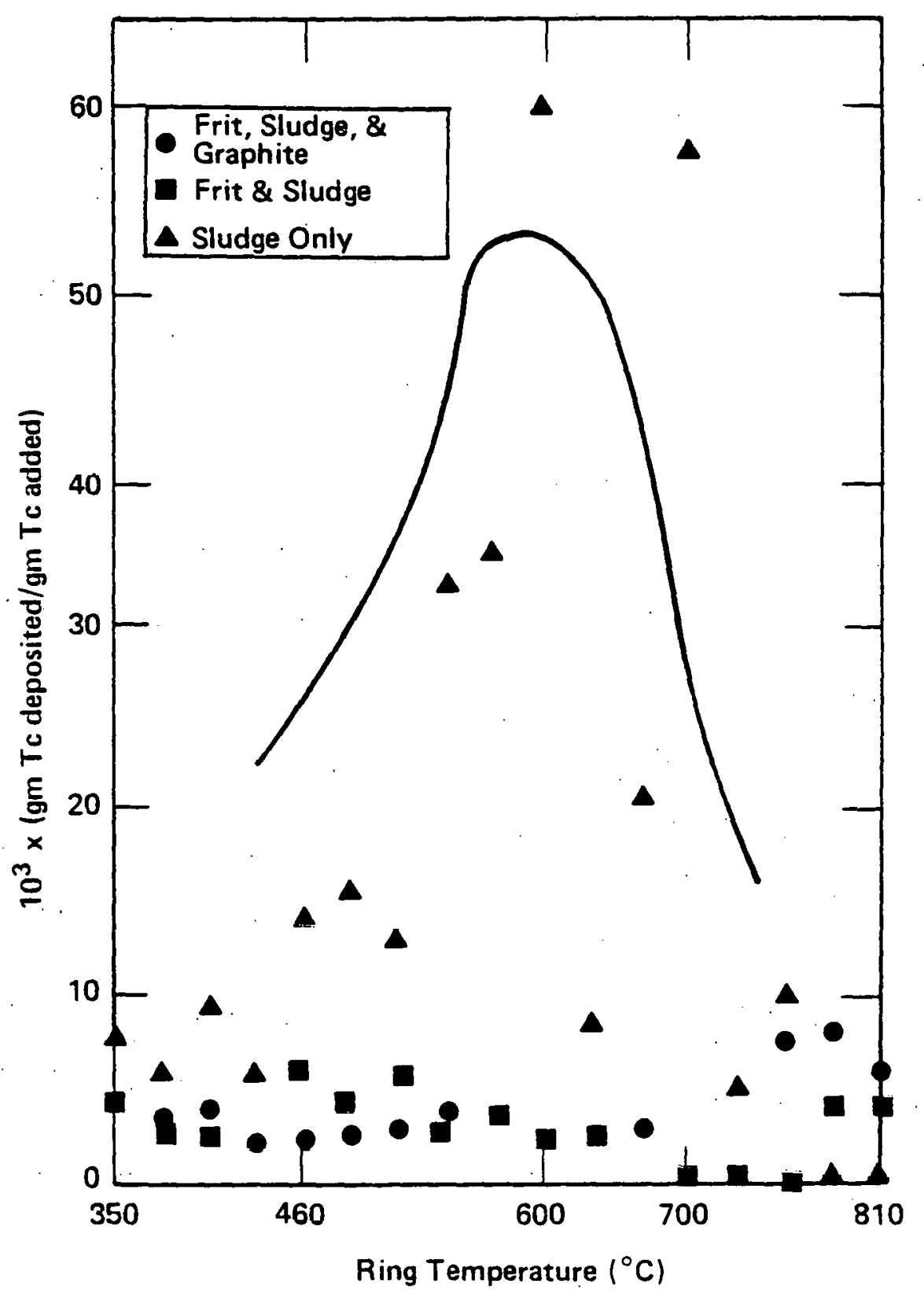

Fig. 2. Deposition of Tc-99 in the semivolatiles trap 